IN SEARCH OF MEANING:

\title{
MOVING FROM THE PROPHET'S VOICE TO PROPHECY IN COMMUNITY; A SOUTH AFRICAN PERSPECTIVE ${ }^{1}$
}

\author{
Ian Nell \\ Practical Theology \& Missiology \\ Stellenbosch University
}

\begin{abstract}
During the times of 'Apartheid South Africa' prophetic preaching played an enormous part in bringing about the changes this country experienced throughout the last three decades. The prophetic preaching of exponents such as Desmond Tutu, Allan Boesak and Beyers Naudé paved the way for the relatively peaceful transitions South Africans experienced. Within Christian communities it assisted people in their search for meaning and thereby created a framework of understanding for the necessity of socio-political change. Fourteen years into the new dispensation the question remains: Does prophetic preaching still make a difference? Also: Does such preaching help Christian communities in their search for meaning in these changing times? These questions will be addressed in the paper. It will be argued that prophetic preaching could and should play a part in a new search for meaning. This should however be practiced anew and under changed conditions. It will also be argued that a 'theodramatic paradigm' provides a helpful practical-prophetic framework in the search for meaning in this regard. Such a framework will be based on the theological model (theorems) provided by classical and recent studies and expanded by applying it to the notion of prophetic performance derived from the Belhar Confession.
\end{abstract}

Keywords: Meaning, Prophetic Preaching, Embodied, Community, Theodramatic Paradigm, Belhar Confession, Local Performance, Regional Theatre, Congregational Action

\section{Introduction}

During the seventh meeting of the Societas Homiletica at the University of Pretoria, South Africa (August 2006) we, as a conference group, had the opportunity to visit the Apartheid Museum in the southern part of Johannesburg. As one of a few South Africans attending this international conference, I had to act as interpreter for some of the group. The whole group stopped for a moment in front of the world famous photograph portraying the youthful Hector Petersen dying in the arms of a friend. The photo of this innocent victim of state violence was taken on 16 June 1976 during the Soweto schools' boycott. Whilst

Paper delivered at the $8^{\text {th }}$ meeting of the Societas Homiletica, Copenhage, Denmark, 20-25 June 2008. The theme of the conference was: In search of meaning: Does preaching make a difference? 
attempting to explain the photo's specific background of to a few Danish scholars, I suddenly realized: This single picture encapsulates the whole apartheid dispensation.

At the time of the uprising I was in secondary school in Potchefstroom, a highveld town less than an hour's drive from the black metropolis Soweto. My father was a military commander of a prestigious unit assigned the task of keeping 'law and order' during those uprisings that set the country aflame. The following year I received the call to study for a minister and thereby started my own search for meaning.

During April 2007 I was sitting in the lounge, visiting a white family and was looking into the eyes of people in deep distress. Ockie Nel, the father, was shot point-blank in front of his wife, daughter and grandchild outside a shopping centre in Durbanville, a relatively safe neighbourhood in the northern suburbs of Cape Town. It happened during a gang robbery by a group of men from a nearby township in the Cape Flats who had been surviving in poor conditions, trying to make a living through violent means. ${ }^{2}$ I suddenly realized that the scene in that family's sitting room somehow captured the face of the new South Africa. How does one comfort a family in such pain and what does 'search for meaning' imply in these circumstances?

By replaying these two scenes I will attempt to picture the different times and changing contexts in which South Africans find themselves. Within these contexts church leaders have been and are still trying to search for meaning and still have to render some sort of prophetic witness of the redeeming work of Christ. These two scenes will serve as a point of reference in the discussion of the context in which this thoroughly existential search for meaning is currently occurring in South Africa. Against this background, as a white DRC theologian, I had to grapple with my own history, my country and my role in the ongoing process.

\section{Methodology}

The practical theological methodology addressing the topic begins by making some comments on a common search for meaning. Next the South African context will be discussed in which this search for meaning is taking place. After a brief look at what we consider the general character of prophetic preaching, one example of prophetic preaching from a South African theologian will be considered. Thereafter we will investigate some of the reasons why prophetic preaching met resistance from the church and church leaders, and thereby in a certain sense lost its nerve and became silent. A theodramatic paradigm will be explored in looking for ways in which prophetic preaching can help us to get out of the impasse. Lastly some suggestions will be made as to why prophetic preaching is currently still totally relevant within the South African context.

\section{The Search for Meaning}

In one's search for meaning, questions about the meaning and purpose of life have a philosophical as well as religious scope. Modernity has led to the influence of a more rational scientific approach concerning an existential quest rather than merely a spiritual

\footnotetext{
For a detailed discussion on the conditions and context of people living in the Cape Flats cf MacMaster, LLM 2007. Resilience of faith communities on the Cape Flats, South Africa - a pastoral theological perspective. Paper read at the $8^{\text {th }}$ World Congress of the International Council on Pastoral Care and Counselling (ICPCC), Krzyzowa, Poland, 7-14 August 2007.
} 
one. It nevertheless remains difficult to separate these two areas of questioning and thought. $^{3}$

Apart from the general and more philosophically-minded search for meaning, we are particularly interested, in this article, in such a search within a religious context. It also places the search for meaning within a theological framework whereby scriptural questions are applied to socio-political realities.

In the classic study, The Meaning and End of Religion, ${ }^{4}$ Wilfred Cantwell Smith demonstrates how we use the word 'religion' in four different senses or 'ways'. According to Smith the first way has to do with personal piety; the second way refers to a system of beliefs, practices and values expressive of what some scholars refer to as particular religious 'world views'; the third way describes religion as social and historical phenomenon embodied in institutions; and the fourth way distinguishes 'religion in general' from other things such as art or politics. ${ }^{5}$

Ninian Smart ${ }^{6}$ applies a similar definition of religion: "Religion is a six-dimensional organism, typically containing doctrines, myths, ethical teachings, rituals, and social institutions, animated by religious experiences of various kinds. To understand the key ideas of religion... one has to understand the pattern of religious life directed towards those goals.",

One can see how prophetic preaching's 'search for meaning' operates within the different senses and patterns in which both Smith and Smart define religion. 'Prophetic' then implies a certain perspective on, or way whereby one attempts to find meaning in the different areas thus defined.

\section{In Search of Meaning: Two Scenes, Separate Contexts}

With the radical changes occurring during the beginning of the nineties in South Africa, one can refer to two different contexts in which the 'search for meaning' took place and is still functioning. These two worlds can be characterised as those 'before' and 'after the fall of apartheid'. 8

\section{Scene 1: Victim of state violence}

The first scene discussed in the introduction took place during the years 'before the fall of apartheid'. That was when a white minority government was ruling the country, backed by a seemingly invincible defense system of military force and state security. It was the era of the perception that citizens were partaking in the defense against communism's expansionism on the borders of the country. Some of my white friends, and even a nephew, died whilst protecting the ideology of this minority regime. As part of the white group we

\footnotetext{
Cottingham, J 2003. On the Meaning of Life. Thinking in Action. London: Routledge, 2.

Smith, WC 1964. The Meaning and End of Religion. New York: Mentor Books.

De Gruchy, JW 2006. Confession of a Christian Humanist. Minneapolis: Fortress Press. 59.

Smart, N 1973. The phenomenon of religion. London: Mowbrays, 42-43.

Ernst Conradie summarized the work of Smart within the South African context in a recent publication. Conradie, E 2006. Waar op dees aarde vind mens God? Op soek na 'n aardse spiritualiteit. Wellington: Lux-Verbi-BM.

8 For a detailed discussion, see: Deegan, H 2001. The Politics of the New South Africa. Apartheid and After. Harlow, England: Pearson Education Ltd.
} 
came from a privileged background ${ }^{9}$ with excellent educational opportunities, but it also meant two years of compulsory military service to help keep the socio-political system intact.

With reference to the first scene, Hector Peterson and his friends were on the receiving end of this political reality. Their education system was exceedingly poor. In addition they had to put up with extremely difficult circumstances to make a living in the huge, widespread townships around the city-fringes in South Africa. It was the times of the group areas act, forced removals, pass laws and the like. These conditions provided the breeding ground for socio-political revolution.

In addition it was a male-dominated society wherein mothers were suffering the most because of the plight of their sons on both sides of the socio-political divide. During the hearings of the Truth and Reconciliation Commission (TRC:1995-1996) some of these stories became public knowledge. Citizens throughout the country were shocked by the enormity of the underlying conflict, hatred and violence that have transpired before the political changes took place.

\section{Scene 2: Victims of societal violence}

The second scene occurred thirteen years into the new South Africa during the time 'after the fall of apartheid.' Considerable political and socio-cultural changes had already taken place, however for millions of the poor in our country these might well not have occurred. ${ }^{10}$ These people are still struggling to make a living. Sometimes they seem forced to resort to brute force to accomplish their means and satisfy their needs. Many of these instances of societal violence are not necessarily because of poverty. The destructive influence of drugs and the detrimental influence of uncontrolled materialism due to the market driven economics and consumer culture provide a mixture of motives. ${ }^{11}$

The first scene, which pictures circumstances during the years 'before the fall of apartheid', provided the backdrop for the development of 'prophetic preaching' in South Africa. The second scene, which sheds light on the other side of the socio-political divide, intensifies the message of the first scene by stressing the need to reach out to one another across the divide.

\section{Characteristics of Prophetic Preaching}

What does this form of preaching entails? In a qualitative analysis of the preaching of Desmond Tutu, Hennie Pieterse (et al) describes prophetic preaching as "one form of preaching, pertaining to social comment and socio-economic and political critique of a society and its body politic." Of crucial importance in taking up the task of prophetic

$9 \quad$ It is interesting to note how even someone like John de Gruchy, a fierce opponent of apartheid over many years, whilst reflecting on his life and work as theologian, refers to his own framework as a 'privileged position' (2005:204).

10 For a detailed discussion on the social issues of poverty and exclusion, see the forthcoming publication of Naas Swart, Meeting the Challenge of Poverty and Exclusion: The Emerging Field of Development Research in South African Practical Theology, in. International Practical Theological Perspectives.

11 For a discussion on the role of the Dutch Reformed Church after 'the fall of apartheid' cf Weisse, W \& Anthonissen, C 2004. Maintaining Apartheid or Promoting Change? The Role of the Dutch Reformed Church in a Phase of Increasing Conflict In South Africa. München: Wasmann Münster. 
preaching is the idea of being "existentially permeated with the context in which one preaches". 12

In similar vein De Klerk writes: "Prophetic preaching enables the community to respond to the critical challenge of social transformation," In that sense one should consider this form of ministering as 'social preaching on justice', which in turn focuses on "fidelity to the community or fidelity to justice for the hungry and oppressed."13

In this sense the life and work of exponents such as Desmond Tutu, ${ }^{14}$ Beyers Naudé, Michael Lapsley and many others are living examples of preachers who have not only been victims of apartheid. They have also actively preached within the church of the poor and not for the church of the poor. This can also be referred to as embodied prophetic preaching, as they laid their bodies on the line. It is thus important that a prophetic preacher truly understands the structural injustices that regulate the lives of people by creating situations of oppression and marginalization. This relates to aspects concerning the political, economical and cultural context of society in which such preachers are operating.

In addition they need to have insight into the moral fibre of the people to whom they are seeking to proclaim the good news about the coming of God's Kingdom. It stands to reason that a thorough social analysis of the context on an ongoing basis is important. The results of empirical research, especially those of the social sciences, are indispensable sources for prophetic preaching. ${ }^{15}$

All of this recalls what the Old Testament prophets taught. De Klerk states that their hallmark is "a message that challenges people to change their attitudes and the status quo of the community; a message that deals with controversial issues and calls for systematic reform". ${ }^{16}$ This is what is in effect meant by embodied ministering.

\section{Embodied Prophetic Preaching}

One can find an example of embodied prophetic ministry and preaching which played a prominent role during and after the apartheid era in the life and teachings of Reverend Dr. Beyers Naudé. He was a former minister in the Dutch Reformed Church and later became director of the Christian Institute from 1963 until it was banned in 1977. Two examples illustrate his prophetic ministry.

12 Pieterse, HJC (ed.) 1995. Desmond Tutu's Message: A Qualitative Analysis. Kampen: JH Kok, 107.

13 De Klerk, B 2007. Preaching Hope within a Societal Context of Hunger and Affluence, in Vos et al (eds.) Preaching as Language of Hope, 200.

14 Thorough research has been done on the prophetic preaching of Archbishop Desmond Tutu by Hennie Pieterse and other scholars, cf: Pieterse, HJC (ed.) 1995. Desmond Tutu's Message: A Qualitative Analysis. Kampen: JH Kok

15 The contributions of the six participants from South Africa during the previous meeting of the Societas Homiletica gave a broad perspective on the many challenges facing prophetic preaching in our context. The contributions were all published in Vos, CJA (et al eds.) 2007. Preaching as Language of Hope: Studia Homiletica 6. Pretoria: Protea Book House and they were: Vos, CJA, Preaching the language of Hope; Mouton, E, Transmitting Hope in the New Testament; Cilliers, JH, Preaching as Language of Hope in a Context of HIV and Aids; De Klerk, B, Preaching Hope within a Societal Context of Hunger and Affluence; Letsoa, R, Preaching Love as a Support Base for the Alleviation of Poverty; Msango, M, Who Touched Me?

16 Cf De Klerk 2007:189. 


\section{To obey God rather than Men}

The first stems from a sermon Naudé delivered on Sunday, 22 September 1963 at the Aasvoëlkop Congregation in Johannesburg. On that occasion he announced his decision to accept the directorship of the Christian Institute of Southern Africa. The theme of his sermon was 'Obedience to God'. The Scripture reading was taken from Acts 5:29 which reads: 'We must obey God rather than men. ${ }^{17}$ Naudé gave an exegeses of the Bible text by highlighting the role of the different characters in the story, including that of the central character Jesus Christ. Naudé concluded: "The Apostles rejoiced that they were counted worthy to suffer for their Master, and they continued with their teaching - disobedient yet at the deepest level obedient, unfaithful, yet faithful at the deepest level". He then went on to explain the implications of this decision of the apostles for his own life, for the community of the Dutch Reformed Church as well as for the ministers in the church. His prophetic words for the ministers as prophets still ring true:

Very many ministers are deeply concerned about the course of events in our Church. Many are concerned because it appears that the Church is not free to act solely on the authority of God's Word because of other influences and powers are playing the dominant role. Many are convinced that great changes will have to take place in our ecclesiastical and race relations on many levels. But for various reasons they suppress these convictions: the fear that if they speak, the Church will be harmed, the fear that our members are not yet ready to accept these truths, the possible repercussions in our congregations. In such a situation we are called to act with the utmost responsibility, but certainly not to remain silent. The proclamation of the truth of the Gospel cannot harm the Church of Jesus Christ! And if our members are not influenced by all sorts of powers but are enlightened fully and fearlessly as to just what the Word of God requires of all people (white as well as non-white), then will the Spirit of God not lead them into all truth? Why then do we fear? Has the time not arrived for us to proclaim clearly and with joy: Thus saith the Lord?

These words were uttered a mere fifteen years after the Nationalist Party came to power in 1948 (after which they ruled for a further 27 years as a minority government). When one takes that fact into account the prophetic quality and implication of this uttering by Naudé are startling.

\section{The Flame of Fire and Sledgehammer}

The second example comes from Naudé's farewell sermon given less than two months later: 'The flame of fire and sledgehammer.' The Scripture reading for this sermon at the Aasvoëlkop Congregation on Sunday, 3 November 1963, ${ }^{18}$ came from Jeremiah 23:29: "Is not my word like fire," declares the Lord, "and like a hammer that breaks a rock in pieces?" Once again after a detailed exegesis on the life and work op the prophet Jeremiah, Naudé posed the existential question: What are the practical consequences of Jeremiah's ministry for the present context?

If, however, we do not let God's Word be for us the renewing fire, then other fires will consume us; if we do not let God's Word be for us the hammer that breaks the rock, then other hammers will destroy us. Hear this, O people of God! With this message this morning I bring to an end my ministry to you - so different from what any of us ever dreamed or

17 The sermon was translated and published in The Legacy of Beyers Naudé, LD Hansen (ed.) 2005:25-29. Beyers Naudé Centre Series on Public Theology.

18 This sermon was also translated and published in The Legacy of Beyers Naudé, 2005:41-45. 
expected. What lies ahead, no one knows - but that is not really the important thing. What is important is that I have always stood in your midst as servant of the Word to bring you the message of God. And even if you forget everything else, if you remember only that for the first four years of the life of this congregation, God sent you somebody who in the midst of many human failings continually tried to summon you and bind you to obedience to God's Word, then my ministry here has not been in vain.

We hear once more the prophetic call of obedience to God's Word by Naudé's use of the rich imagery of fire and hammer whereby he clearly distinguished between God's will and human failings. It is no wonder that the well-known church theologian John de Gruchy summarizes Naudé's ministry, stating that Naudé became the figurehead in the global struggle against apartheid. Although Naudé was acknowledged throughout the world for taking that stance, he was a prophet without honour in the (then white) South Africa. He nevertheless was an inspiring example to many seeking to find their way in the mire. De Gruchy fondly discerns: "He was ... a true Christian humanist whose ecumenical vision, solidarity with the victims of apartheid and concern for justice and peace arose out of a deep faith in the Gospel."19

\section{Why the Loss of Nerve?}

The initial wave of responses from churches and church leaders to the challenges of these documents and to the prophetic preaching as illustrated by the sermons of Naudé, is very instructive. According to Van der Water we can distinguish four main reasons why the reaction was not one of enthusiasm: ${ }^{20}$

The first, as mentioned above, stems from the nature and problem of institutionalised ecclesiastical authority in what Van der Water describes as "a distinct over-sensitiveness amongst church leaders about their actual or fallacious institutionalized ecclesiastical authority."

The second reason Van der Water refers to as "trapped within an iron cage of history", ${ }^{21}$ In this he refers to the research of Pieterse, who cites the sociological perspectives of Yorick Spiegel who in turn makes use of the work of Max Weber. The aim is to disclose how the ministry of most Protestant churches is undermined by bureaucratic structures. Ironically it is the need for well-oiled organization within the church that results in such a trend. Once again Van der Water connects the bureaucratic problem with institutionalism: "The question is not whether but to what extent the trap of institutionalism disempowers and incapacitates the churches, leaving them at best, making prophetic soundings and, at worst, woefully lacking in prophetic and transforming action.'

A third reason Van der Water mentions, is "failing to discern "the signs of the times". He gives a decisive diagnosis: "It was precisely the non-alertness to and lack of discernment by the churches which prevented them from realizing the opportunities which emerged out of the historical moment of crisis in 1985. It was a crisis, and in the key term of the KD, a kairos which was brought about, on the one hand, by wide scale and brutal

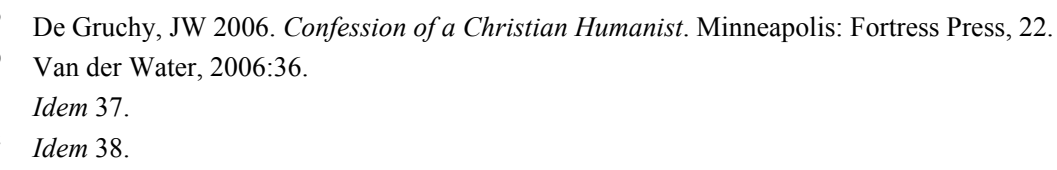


repression in the townships, and on the other hand, the upsurge of resistance amongst popular movements." 23

The fourth and final reason Van der Water discusses, is "the problem of the churches' amnesia..." He urges the church to recognise that this amnesia is the present result of extensive socio-historical processes. Centuries of social institutionalism had the effect of alienating the church in general from its true theological essence. Therefore "the many layers of social engineering leaves the Church theologically disorientated and often out of touch with its raison d'être." This theological disorientation and loss of essential awareness of the church's unique identity leads to a situation where it becomes entangled in "an allconsuming preoccupation with the maintenance of the Church as institution". ${ }^{24}$

DJ Smit however is of the opinion the main reason for the 'loss of nerve' is that there is no longer a 'struggle church' opposing a common enemy. The result is that most churches have withdrawn into their own spheres of denominational activities. "Attempts to recover the prophetic ecumenical spirit and to engage churches in a common struggle against for example HIV/Aids or the disastrous effects of the global economy have mostly proven to be without visible success. ${ }^{, 25}$

Van der Water concludes by giving the following summary and posing applicable open questions:

Given the fact that the institutionalized churches, by their very nature, cannot be relied upon to provide the well-spring for a dynamic prophetic Christianity, the question arises as to who shall provide the source or sources for an ongoing contextual and charismatic prophetic theology and praxis? ... Where shall the churches derive the vision from which it could direct them on the way to embarking on theological paradigm shifts which make them more mission-driven and less maintenance-orientated $?^{26}$

These decisive questions need to be tackled and translated into the prophetic preaching ministry of the church. But it is firstly important to consider some other broader societal influences that impact on the challenge of prophetic preaching. This will guide one in the search for meaning, which is not such an easy undertaking in post-apartheid South Africa!

\section{'Collapse into Modernity'}

Together with the reasons Van der Water and others put forward for the non-enthusiastic reaction to prophetic preaching in apartheid South Africa, are also broader influences and changes that help to explain why prophetic preaching is still facing serious challenges in the post-apartheid environment.

South African society is currently experiencing what Smit calls a "collapse into modernity. ${ }^{27}$ According to him 'modernity' in this context would imply "social forces and

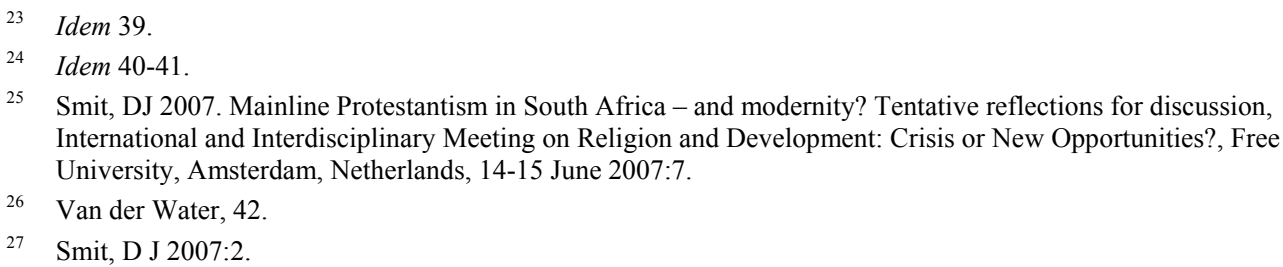

5 Smit, DJ 2007. Mainline Protestantism in South Africa - and modernity? Tentative reflections for discussion, International and Interdisciplinary Meeting on Religion and Development: Crisis or New Opportunities?, Free University, Amsterdam, Netherlands, 14-15 June 2007:7.

26 Van der Water, 42.

27 Smit, D J 2007:2. 
institutional forms - secularization, industrialization, bureaucratization - that embody the Enlightenment ideals of rationality, individual autonomy, and progress". ${ }^{28}$

$\mathrm{Smit}^{29}$ goes on to discuss six material claims which explain this unfortunate collapse.

- Firstly during the past fifteen years in South African society major social transformations were effected which have been radical, dramatic and comprehensive. Smit reiterates: "The country moved overnight into a process of what could be called radical modernization and in many ways it still finds itself in the dynamics of this historical process."

- Secondly, the churches "were part and parcel of this transformation" because the Protestant and in particular Reformed Churches were previously involved in the formation and justification of apartheid. Some Reformed Churches were however deeply involved in the struggle against apartheid and the striving for democracy, freedom and social justice.

- Thirdly 'no single theoretical approach' can describe what has been taking place in South Africa to date. According to Smit these theoretical frameworks may contribute valuable insights but no ready-made theory will be sufficient as such. In this sense it is better to view modernization as an ongoing process which is difficult to define.

- Fourthly, a global perspective, in other words making use of contemporary theories of globalization, will be of great importance in order to comprehend the changes taking place in the country. In this instance Smit concludes: "It is therefore helpful to see globalization as in fact the intensified and accelerated form of modernization ... and it is in this form that South Africa today is being challenged and transformed by processes of modernization."

- Fifthly one has to understand that the churches in South Africa are themselves on the receiving end of these contemporary global processes of modernization. "They are not merely actors, but they are being acted upon. It is not as if they are totally free to decide whether they will contribute to modernization, to development and progress. They themselves first of all undergo modernization... in these particular forms."

- Lastly, Smit discusses the way in which one uses the term 'church', because the church exists in very specific 'concrete and visible, social forms.' Smit distinguishes three basic forms of the church namely regular worship and local congregational life; the policies and practices of denominations and the ecumenical church; the spirituality, witness and actions of individual believers. It is interesting to note how and why the prophetic voice became silent during the past fourteen years in all three forms of church life which Smit distinguishes.

\section{The Way Forward?}

These comments challenge one to consider the following questions: What can be done to nurture the prophetic impulses of preaching in an ongoing search for meaning? How can the church leaders in South Africa rescue the prophetic critique from being submerged under other searches for meaning in this new democratic dispensation? How can the exponents of such a ministry enhance a paradigm for prophetic preaching?

28 Vanhoozer, KJ 2003. Theology and the condition of postmodernity: a report on knowledge (of God), in Vanhoozer (ed.) 2003. The Cambridge Companion to Postmodern Theology. Cambrigde: University Press, 7.

29 Smit, 2007:2-4. 
Van der Water suggests the following guidelines in a search for meaningful answers: "The basis for a solution to the above must surely be sought in conjunction with an appreciation for and appropriation of the paradoxical nature of the church itself, namely that the church has been constituted and historically sustained by both charisma and institutional structure. ${ }^{30}$

I agree [concur] with Van der Water's inclination, but nevertheless propose that one's quest ought to begin by retracing one step. One first has to consider the epistemological starting point of a 'paradigm for prophetic preaching'. In other words, before focusing on the institutional and charismatic nature of the church, let us first ask what we ourselves understand by a new paradigm for prophetic preaching.

\section{A Theodramatic Paradigm for Prophetic Preaching}

In light of this I would like to propose a new paradigm for such ministry and preaching. The 'theodramatic paradigm or horizon' for practicing theology, is not a new theorem. Von Balthasar already wrote his major work on Theodrama in $1983 .{ }^{31}$ Relatively new however is the application and implementation of this paradigm in the field of practical theology and homiletics. ${ }^{32}$ Healy elucidates on this usage:

A theodramatic horizon or metanarrative is particularly appropriate for reconfiguring ecclesiology as a practical-prophetic discipline. This is because it can hold together in tension a number of elements that otherwise may be confused or separated or treated one-sidedly. These tensive elements include the following: the churches identity is fully constituted by both divine and human agency, permitting theological reflection upon the concrete church; the church's role includes the formation of the individual disciple's distinctive identity; the church's orientation renders it superior to others, yet it is dependent upon others and is always more or less sinful; the church claims to be orientated to ultimate truth, yet it must acknowledge that our view of that truth is limited by our location within the ongoing drama. ${ }^{33}$

Smith points out the primary responsibility this paradigm entails for the church within a North American context. The postmodern church acknowledges its main responsibility: to live (i.e. act out) the story of salvation for the world. In light of the church being seen as the stage where God's drama is played out, Christians have a certain responsibility. Smith stresses the need "to 'act well', we might say, to faithfully play out the love of God in the church as community of love and justice. Our storytelling should be supported by our story

$30 \quad$ Van der Water, 2003:39.

31 Von Balthasar. HU 1983. Theo-Drama: Theological Dramatic Theory: V: The Last Act. San Francisco: Ignatius Press.

32 In recent times we saw the publications of several scholars in making use of a theodramatic approach to theology and also to practical theology. See for example: Healy, NM 2000. Church, World and the Christian Life: Practical-Prophetic Ecclesiology. Cambridge University Press. Horton, MS 2002. A Better Way: Recovering the Drama of God-Centered Worship. Grand Rapids: Baker. Vanhoozer, KJ 2005. The Drama of Doctrine: A Canonical-Linguistic Approach to Christian Theology. Louisville: Westminster John Knox; Quash, B 2005. Theology and the Drama of History: Cambridge Studies in Christian Doctrine. Cambridge: Cambridge University Press; Osmer, RO 2005. The Teaching Ministry Of Congregations. Louisville: Westminster.

33 Healy, 2000:22. 
living" ${ }^{34}$ This proposal applies equally to the challenges facing the churches within the current South African context.

Prophetic preaching in search of meaning, defined within this paradigm, will then be part of the Christian tradition's inquiry into how best to respond to Jesus Christ. It will also help to provide new avenues within which the church can comprehend and express itself as a communal embodiment of that inquiry. That could be done by providing a clear prophetic alternative by acting as a community of love and justice.

\section{Prophetic Preaching as Part of Regional and Local Theatre}

Vanhoozer takes his cue from George Lindbeck and others who locate the criteria of Christian identity in Spirit-led church practices. Building on this criteria he details how doctrine serves the church - the theatre of the gospel - by directing individuals and congregations to participate in the drama of God's action to renew all things in the Lord Jesus Christ. In the book's last chapter with the heading: "Creeds, confessions, and the pastor/director" Vanhoozer considers doctrine and the practice of theology within the theatre of congregational action. ${ }^{35}$

Vanhoozer starts the chapter by stating: "The church is a company of amateurs who gather together to do holy and vital theater: of the gospel; of word and sacrament; of martyrdom; of reconciliation; of holy folly. How on earth does one organize such a production?" ${ }^{36} \mathrm{He}$ goes on to discuss four aspects of organizing 'such a production': directing the company as pastoral theology, masterpiece theatre as creedal theology; regional theatre as confessional theology and local theatre as congregational theology. He neatly summarizes this theodramatic approach:

Doctrine is a condensed form of Christian wisdom, rooted in the Scriptures and accumulated over the centuries, about how rightly to participate in the drama of redemption, which is to say, in the life of the triune God. To recapitulate: the Father is the playwright and producer of the action; the Son is the climax and summation of action. The Spirit, as the one who unites us to Christ, is the dresser who clothes us with righteousness... While the Holy Spirit is the primary director who oversees the global production, it is the pastor who bears the primary responsibility for overseeing local performances. The pastor is an assistant director at best, assisted in turn by the theologian as dramaturge. Ideally, the pastor is also a theologian. In any event, the pastor is also a player in the drama who directs as much by example as by precept. The director is the mediator between the script and the actors. ${ }^{37}$

Further refining the image of the pastor as director, the first commandment of the director according to Vanhoozer, is obedience to the text. Therefore the analysis of the play is of major importance in directing the process of preaching in this instance. In addition the director has to communicate the interpretation of the script to the actors and audience, train

4 Smith, JK 2006. Who's afraid of postmodernism? Taking Derrida, Lyotard and Foucault to church. The Church and Postmodern Culture. Grand Rapids: Baker Academic, p.77.

35 Vanhoozer, 2005:445-457.

36 Vanhoozer 2005:445.

37 Vanhoozer, 2005:448. Upon reflecting briefly on the prophetic life, work and preaching of Beyers Naudé, we recognize the different aspects of the approach Vanhoozer identifies. In this sense it is quite ironic to learn from Naudé's story that some of his best "performances as actor in the drama" were when he was actually not allowed to play his role in public. But that did not keep him from directing from behind closed curtains as mediator between the script and the actors at large. 
the actors and get them to work together. Vanhoozer stresses the fact: "What the pastor/director really needs to do is take the congregation's imagination captive to the Scriptures so that the theodrama becomes the governing framework of the community's speech and action (2 Cor 10:5)". ${ }^{38}$ Herman Mellville's image whereby 'the pulpit leads the world' like a ship's prow breaks through uncharted waters, is striking in this regard. ${ }^{39}$

\section{Getting the Act Together}

Without getting entangled in excessive detail about the role of the (prophetic) pastor as director and player in the drama of local theatre, I want to concentrate on certain aspects concerning the 'plot' for prophetic preaching. Here theology plays a crucial role in offering direction with regard to the actions and events of the plot. In this interaction between the pastor as 'assistant director' and the other congregational role-players, the local theatre of congregational theology turns into a prophetic community. That is because "the church communicates the meaning of the play through its bodily action." 40

It was Leslie Newbegin who described the faith community as 'a hermeneutic of the gospel'. ${ }^{41}$ In this sense it is comforting to know that the pastor and his/her company of actors do not have to start from scratch. There is always a prior performance history to fall back on, indeed a history of 'great performances.' In this creedal and confessional theology is of great help at a time when too many contemporary Christians "know neither the script nor these great performances." ${ }^{, 2}$ By acting as apprentice to creedal theology the prophetic preacher in conversation with the congregants helps the local church to understand its role in the light of the universal church. In that sense one also realizes that the local church is not the first company attempting to stage performances from Scripture content.

Confessional theology goes further and assists the preacher "by mediating between the universal (catholic) and particular (local)." This entails a distinct development since the Reformation in the sixteenth century because of "the lack of consensus about how to resolve theological debates ... (and) because they addressed problems that affected their time and space." ${ }^{43}$ Because of this development one can now speak of 'regional theatre.'

Confessional theology wasn't limited to the sixteenth and seventeenth centuries. A next wave of this form of theology came into prominence during the twentieth century. Prime examples thereof were the Barmen (Germany) and Belhar (South Africa) Confessions. Both status confessiones operated as prophetic witnesses each within their respective contexts. In that sense confessional theologies form part of the 'great performances' as responses to their own historical context. They thereby also contain lessons for the church as a whole.

Vanhoozer summarizes: "While they invariably affirm the ancient creeds, they also respond to further complications and questions concerning the best way to understand the theodrama in specific cultural and intellectual contexts. Perhaps it is best to think of

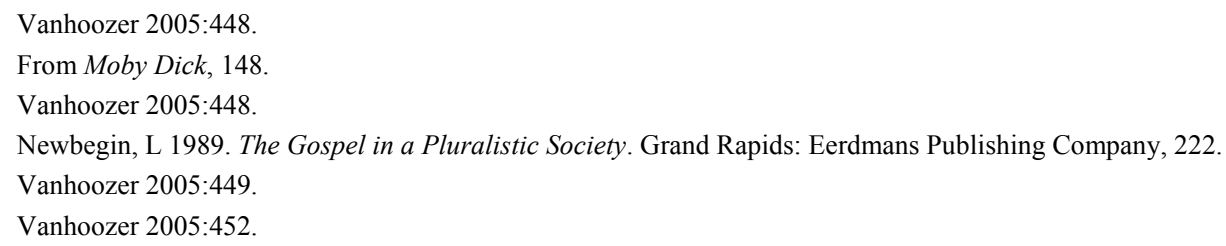


confessional theology as local performances with staying power, and thus of more than local interest only." 44

\section{Belhar and Prophetic Performance}

In this concluding section I want to make use of the Belhar Confession as an example of 'prophetic local performance.' By using this Confession's underlying theological framework as a guide I want to single out at least 'three acts of the plot' when one accepts the challenge of performing prophetic preaching within a South African context in search of meaning. I shall describe these three acts as: "taking hands, embracing each other and giving back the bicycle" (a contextual idiom that will be explained in full).

\section{'Taking Hands' (Unity)}

The Belhar Confession's first article centres on 'unity'. Many articles and books have been written on this topic. I therefore only want to stress one aspect of this prophetic action. ${ }^{45}$ The topic is the ongoing struggle to recognize the other within the South African context. With regard to the Dutch Reformed Church the complex set of relationships with the other (cultural, religious, gender) is shown still to be the most important factor in the struggle to construct a Christian identity (and that being after the changes of 1994). ${ }^{46}$

Prophetic preaching aims to express the dynamic relationship between God and the world, as portrayed in the story of the covenant people of Israel, and thereafter in the birth, life, death and resurrection of Jesus of Nazareth. Therefore this form of preaching has the responsibility to demonstrate the many different ways in which people can and must 'take hands' through accepting these 'others.' In such a diverse country with a history of 'enclavement ${ }^{47}$ it is necessary never to cease the prophetic call to reach out with open arms and cross the many different divides between people.

At this stage one can briefly recall the examples (two scenes on different sides of the divide) with which this article started as well as the view on the development in the life and preaching of Beyers Naudé. In light of these instances one realizes the importance of the prophetic imperative 'to take hands' in the plot development of local and regional theatre. In the so-called 'post modern world' globalization has expanded beyond many boundaries but at the same time created religious and ethnic fragmentation that resulted in widespread polarization. Therefore 'taking hands' would be a central act in regional and local theatre.

\section{'Embracing each Other' (Reconciliation)}

The second article in the Belhar Confession focuses on 'reconciliation and forgiveness.' Almost ten years ago after attending hearings of the Truth and Reconciliation Commission a columnist wrote in the Daily News: "The sad truth is that, for a whole host of reasons,

44 Vanhoozer 2005:453.

45 For example: Smit, DJ 2003. Unity in church and society? - theological reflections on an ongoing challenge in South Africa today. Scriptura 83:305-314.

46 See, Aaboe, J 2007. The Other and the construction of cultural and Christian identity: The case of the Dutch Reformed Church in transition. Unpublished Dissertation, University of Cape Town.

47 Aaboe, 2007:62-68 makes use of Mary Douglas' Enclave Theory to show the many ways in which the global resurgence of ethnic and religious enclaves once again challenge the identity of Christians, and the way in which we are still battling with the notion of difference [separateness?]. 
South Africans are not any more reconciled to one another now, especially across racial divides of old, than they were before the inception of the Commission." $\$ 4$

It is obvious that individual believers, faith communities and denominations have a lot of unfinished business within South African society. It is quite evident that reconciliation will be futile if we do not get to the root of the pathological socio-economic structures that further unemployment and ongoing poverty especially in black communities. In this regard South Africans are in desperate need for initiatives that seek to address the multiple economic, social and political problems in this country.

Prophetic preaching implies a call to faithfulness and spiritual renewal characterised by a genuine love for others (1 Cor 2:13-16). It is all about spiritual discernment and a response to Jesus' mandate according to Luke $4: 18$. $^{49}$ This means to operate with, in the words of Allan Boesak, 'the tenderness of conscience,' in other words with the prophetic cry that 'this must not be. ${ }^{50}$

Prophetic preaching on reconciliation and forgiveness should be accompanied by initiatives illustrating the importance and need to revisit the past through narrative and storytelling. The preaching process should create spaces where people feel safe to bring the victims and victimizers into authentic relationships. Such relationships would be characterized by acknowledgment of past injustices and the willingness on both sides of the divide to engage in a process of forgiveness and reconciliation.

One such initiative, in which I had the privilege to participate, forms part of the Institute for the Healing of Memories in which Father Michael Lapsley ${ }^{51}$ plays a leading role. Congregation members of previously advantaged and disadvantaged communities follow a specific programme. It usually takes place during a weekend and is set in an 'island situation' where storytelling stands central. The weekend closes with a worship service in which each participant partakes, with the sharing of the Eucharist as the final act. ${ }^{52}$

To create such a zone of reconciliation is one of the largest contributions of faith communities to the process of reconciliation and forgiveness in this country. At the same time these acts become prime examples of local theatre where all who partake play a significant role in the ongoing theodrama.

\section{'Giving Back the Bicycle' (Justice)}

The actions of 'taking hands' and 'embracing each other', are linked closely with the third part of the act, namely 'giving back the bicycle.' Michael Lapsley explains this act as follows: "Bicycle theology is when I come and steal your bicycle. Six months later I come back to you and admit that I am the one who stole your bike. I am sorry I stole your bike. Please will you forgive me? Because you are a Christian, you say: Yes, I do forgive you. Of course I keep the bike. ${ }^{, 53}$

48 Daily News, Wednesday, 11 August 1999.

49 See Goba, B 2003. The quest for truth and reconciliation: A prelude to new expressions of humanity and sprituality, in Speckman \& Kaufmann (319).

50 Boesak, A 2005. The Tenderness of Conscience: African Renaissance and the Spirituality of Politics. Stellenbosch: Sun Press.

51 For an interesting account of the life and work of Father Michael Lapsley, see: Worsnip, M 1996. Michael Lapsley: Priest and Partisan, A South African Journey. Ocean Press.

52 For the work of the Institute for the Healing of Memories visit: www.healingofmemories.co.za

53 Lapsley, M 2000. Column, in: Sunday Independent, $11^{\text {th }}$ of June. 
It should be obvious that the kind of theology Lapsley exposes implies no more than 'cheap grace' and a misperception of forgiveness that not helping the cause of justice. Much more is needed to effect authentic reconciliation. Regional and local theatre in the form of prophetic preaching can help in imaginative ways to facilitate these processes. Bonganjalo Goba writes: "Many of us especially in the religious communities have realized that reconciliation as a pursuit to promote justice is no longer just an option but a moral imperative. It is a challenge to choose who we are as we build a new society."

By translating this practice into theodramatic terms (i.e. the enactment of 'giving back the bicycle') preachers are continually getting clarity on their supposed roles in helping to build a new society. Throughout this process they become witnesses to society in general of the ways in which each and everyone can play these roles with integrity.

The Institute for Church-led Restitution is one amongst many similar organizations that minister to religious communities by facilitating this important act of justice in our country. ${ }^{55}$ By their practices it becomes clear that the South African community needs more than just a social enactment of 'giving back the bicycle'. The following quotation illustrates the point: White people, I wish you can understand that we don't want your houses, your money or your jobs ... we want your hearts, your friendship, your love. We want you!

These words uttered by an unemployed, thirty-something father and member of the Uniting Reformed Church in Khayelitsha at the (before mentioned) Healing of Memories and Restitution workshop, made a touching and far-reaching impression. Being a black South African Christian he doesn't in the first place think about restitution in monetary terms. This member of the black community isn't primarily interested in white people's material possessions. He yearns for something simple but of greater significance - for white people to give themselves!

\section{Conclusion}

We thus propose a new relevant paradigm for prophetic preaching, operating with the above-mentioned plot in three acts as part of the theodrama. Such a form of preaching in search of meaning faces many challenges on the ever-changing stage of practicing theology in Southern Africa. Dramatic changes are currently (2008) playing out in the political arena (change of presidents, xenophobia, party politicking) and on the economic stage (worldwide recession, electricity cuts and the resulting job losses). With the availability of such a dramatic script there is the proverbial 'never a dull moment' in the local and regional theatre of prophetic preaching.

The 'theodramatic horizon' opens new avenues of approaching the challenges facing South African society. It invites all role players to partake with head, heart and hand in the ongoing drama of structuring new Christian identities in a continent full of drama. ${ }^{56}$ Some of the essential questions with which church leaders and members of religious communities constantly have to deal are:

4 Goba, 2003:317.

55 One other example is the work of the Diakonia Council of Churches, with the Oikos Journey as one of their publications with prophetic critique on the socio-economic situation in our country and constructive suggestions to address the problem.

56 John de Gruchy (2006:159) adds to the economic and political forces also religious ideologies and pervasive secularism as some of the major prophetic challenges facing the preaching process. 
- Where do we fit into the plot of the Holy Spirit as true Director?

- What are our main responsibilities as prophetic preachers in overseeing local performances in search of meaning?

- What is our own relationship to the main Actor in this plot, Jesus Christ?

A shift is necessary from prophetic individuals to prophetic communities which participate in the theodrama, and react to the invitation of the main Character. This inclination not only helps prophetic preachers in their search for meaning, it also creates new energy in helping them to fulfill their roles in the ongoing drama. Prophetic preaching seen from this perspective certainly does have an important part to play in the common search for meaning in post-apartheid South Africa and indeed through the ministry of religious communities worldwide.

\section{BIBLIOGRAPHY}

Aaboe, J 2007. The Other and the Construction of Cultural and Christian identity: The Case of the Dutch Reformed Church in Transition. Unpublished Dissertation, University of Cape Town.

Boesak, A 2005. The Tenderness of Conscience: African Renaissance and the Spirituality of Politics. Stellenbosch: Sun Press.

Botha, J \& Naudé, P 1998. Op pad met Belhar: Goeie nuus vir gister, vandag en môre. Kaapstad: Van Schaik.

Conradie, E 2006. Waar op dees aarde vind mens God? Op soek na 'n aardse spiritualiteit. Wellington: Lux-Verbi-BM.

Cottingham, J 2003. On the Meaning of Life. Thinking in Action. London: Routledge

Deegan, H 2001. The politics of the new South Africa. Apartheid and After. Harlow, England: Pearson Education Ltd.

De Gruchy, JW 2006. Confession of a Christian Humanist. Minneapolis: Fortress Press.

De Klerk, B 2007. Preaching hope within a societal context of hunger and affluence, in Vos et al (eds.) Preaching as Language of Hope.

Goba, B 2003. The quest for truth and reconciliation: A prelude to new expressions of humanity and sprituality, in Speckman \& Kaufmann Hansen LD (ed.) 2005:25-29. The Legacy of Beyers Naudé. Beyers Naudé Centre Series on Public Theology.

Healy, NM 2000. Church, World and the Christian Life: Practical-Prophetic Ecclesiology. Cambridge University Press.

Horton, MS 2002. A Better Way: Recovering the Drama of God-Centered Worship. Grand Rapids: Baker.

MacMaster, LLM 2007. Resilience of faith communities on the Cape Flats, South Africa a pastoral theological perspective. Paper read at the $8^{\text {th }}$ World Congress of the International Council on Pastoral Care and Counselling (ICPCC), Krzyzowa, Poland, 7-14 August 2007.

Newbegin, L 1989. The Gospel in a Pluralistic Society. Grand Rapids: Eerdmans Publishing Company.

Osmer, RO 2005. The Teaching Ministry of Congregations. Louisville: Westminster. 
Pauw, JC 2005. The life and legacy of Beyers Naudé, p.18, in LD Hanson (ed.) 2005. The Legacy of Beyers Naudé: Beyers Naudé Centre Series On Public Theology: Volume 1. Stellenbosch: Sun Press.

Pieterse, HJC (ed.) 1995. Desmond Tutu's Message: A Qualitative Analysis. Kampen: JH Kok.

Quash, B 2005. Theology and the Drama of History: Cambridge Studies in Christian Doctrine. Cambridge: Cambridge University Press.

Smart, N 1973. The Phenomenon of Religion. London: Mowbrays.

Smit, DJ 2003. Unity in church and society? Theological reflections on an ongoing challenge in South Africa today. Scriptura 83:305-314.

Smit, DJ 2007. Mainline Protestantism in South Africa - and modernity? Tentative reflections for discussion, International and Interdisciplinary Meeting on Religion and Development: Crisis or New Opportunities?, Free University, Amsterdam, Netherlands, 14-15 June 2007.

Smith, J K 2006. Who's afraid of postmodernism? Taking Derrida, Lyotard and Foucault to church. The Church and Postmodern Culture. Grand Rapids: Baker Academic.

Smith, WC 1964. The Meaning and End of Religion. New York: Mentor Books.

Swart, N 2008. Meeting the Challenge of Poverty and Exclusion: The Emerging Field of Development Research in South African Practical Theology. International Journal for Practical Theology.

Van der Water, D 2001. A legacy for contextual theology: Prophetic theology and the challenge of kairos, p. 33, in Speckman, M T \& Kaufmann, LT 2001. Towards an Agenda for Contextual Theology. Essays in Honour of Albert Nolan. Pietermaritizburg: Cluster Publications.

Vanhoozer, KJ 2003. Theology and the condition of postmodernity: a report on knowledge (of God), in Vanhoozer (ed.) 2003. The Cambridge Companion to Postmodern Theology. Cambrigde: University Press.

Vos, CJA (et al eds.) 2007. Preaching as Language of Hope: Studia Homiletica 6. Pretoria: Protea Book House.

Von Balthasar. HU 1983. Theo-Drama: Theological Dramatic Theory: V: The Last Act. San Francisco: Ignatius Press.

Weisse, W \& Anthonissen, C 2004. Maintaining Apartheid or Promoting Change? The Role of the Dutch Reformed Church in a Phase of Increasing Conflict in South Africa. München: Wasmann Münster.

Worsnip, M 1996. Michael Lapsley: Priest and Partisan, A South African Journey. Ocean Press. 